\title{
HEAVY METAL ACCUMULATION IN LEAVES OF HYDROCHARIS MORSUS-RANAE L. AND BIOMONITORING APPLICATIONS
}

\author{
Ludmiła POLECHOŃSKA ${ }^{1}$, Małgorzata DAMBIEC \\ University of Wrocław, Department of Ecology, Biogeochemistry \\ and Environmental Protection, Wrocław, Poland
}

\begin{abstract}
In present study the concentrations of $\mathrm{Hg}, \mathrm{Mn}, \mathrm{Zn}, \mathrm{Fe}$ and $\mathrm{Cu}$ in water, bottom sediments and leaves of Hydrocharis morsus-ranae from 11 oxbow lakes of the Odra River were determined by atomic absorption spectrometry. Trace metal concentration in water and bottom sediments were below the geochemical background, indicating no anthropogenic impact in the studied area. On average, the concentrations of metals in leaves of $H$. morsus ranae exceeded natural thresholds. A high bioaccumulation factors for metals were recorded. The significant positive correlations found between the content $\mathrm{Zn}, \mathrm{Fe}$ and $\mathrm{Hg}$ of in water and in the H. morsus ranae indicate the potential use of the species in the biomonitoring of environmental contamination with these metals.
\end{abstract}

Keywords: $\quad$ trace metal, Hydrocharis morsus ranae, metal accumulation, biomonitoring

\section{INTRODUCTION}

Aquatic ecosystems are often the terminal link of pollutant migration. Water bodies of urbanized and agricultural areas are exposed to a strong anthropogenic influence. The increased input of trace metals and biogenic elements into these ecosystems is an urgent problem [13]. Sources of trace metals in water are: industry, agricultural discharge (containing mineral fertilizers and plant

\footnotetext{
${ }^{1}$ Corresponding author: University of Wrocław, Department of Ecology, Biogeochemistry and Environmental Protection, ul. Kanonia 6/8, 50-328 Wrocław, Poland, e-mail: polechonska@gmail.com, tel. +48713752011
} 
protection chemicals), atmospheric pollution such as acid rains and, frequently overlooked, domestic wastewater [10, 27].

Macrophytes play prominent role in biogeochemical cycles of nutrients and heavy metals of many aquatic ecosystems [24]. Some authors indicate aquatic plants as biomonitors for aquatic ecosystems state because of high accumulation ability of a great amount of various substances, among them metals, in plant organs [3, 25]. Many aquatic plants can accumulate considerable amounts of metals dissolved in water and retain them in organs for a long time. In that case analyses of plant tissues provide time-integrated information about quality of the system [3,13]. Some aquatic plants can accumulate several ten to several thousand times higher concentrations of metals than in their surroundings [18, 24] and at a level correlated with their water or bottom sediment concentration [15]. Because of these abilities, and also high production of biomass, some macrophyte species have been successfully used as biological monitors and remediators of habitats contaminated with heavy metals. The indicator plant species should be: native to the area; easily cultivated and abundant in the field; visible to the naked eye; easy to collect and to handle; easy to identify in the field [6]. In order to obtain accurate indicators of aquatic ecosystem, it is necessary to apply parallel studies on the content of elements in water and sediments [2].

European frog-bit is the only species of the Hydrocharis genus native to Poland. It is an annual, herbaceous, free-floating, or rooted, when on mud, aquatic plant [23]. The plant grows best in stagnant water habitats such as swamps, backwaters, quiet areas of bays, low energy shorelines of rivers, streams and lakes [16]. Some authors $[2,5,10]$ suggest potential use of this species as a phytoindicator or a phytoremediator in aquatic ecosystems. Moreover, Hydrocharis morsus-ranae confirms very well many of the above-mentioned criteria for the good biomonitor organism. Free-floating plants should be used in biomonitoring of water quality in place of rooted species since they draw their nutrients from the water column [6]. Still, there are only a few studies available regarding the capacity of $H$. morsus-ranae to accumulate metal ions from aquatic environment.

The aim of this study was to assess bioaccumualtion of metals in H. morsusranae in relation to metal concentration in surrounding environment and to evaluate whether this species could be usefully employed in the bioindication by bioaccumulation methods. We evaluated the concentrations of $\mathrm{Hg}, \mathrm{Mn}, \mathrm{Zn}, \mathrm{Fe}$ and $\mathrm{Cu}$ in water, bottom sediments and leaves of H. morsus-ranae. 


\section{MATERIAL AND METHODS}

\subsection{Study area}

The investigations were made in the north part of Lower Silesia, near Wołów and Ścinawa (Fig. 1). The study sites were designated in 11 ponds where populations of $H$. morsus-ranae were particularly rich. Study sites were mainly oxbow lakes of the Odra River that are small, permanent water bodies characterized by significant fluctuations in water levels. These ponds are used for a variety of purposes, including recreation, livestock watering and fishing. Some sampling sites (1-7) were located in the wooded region rich in backwaters and swamps which create poor conditions for an intensive development of agriculture and therefore it has a relatively low concentration of farming activity. Other sampling sites (8-11) were located in an agricultural region [26].

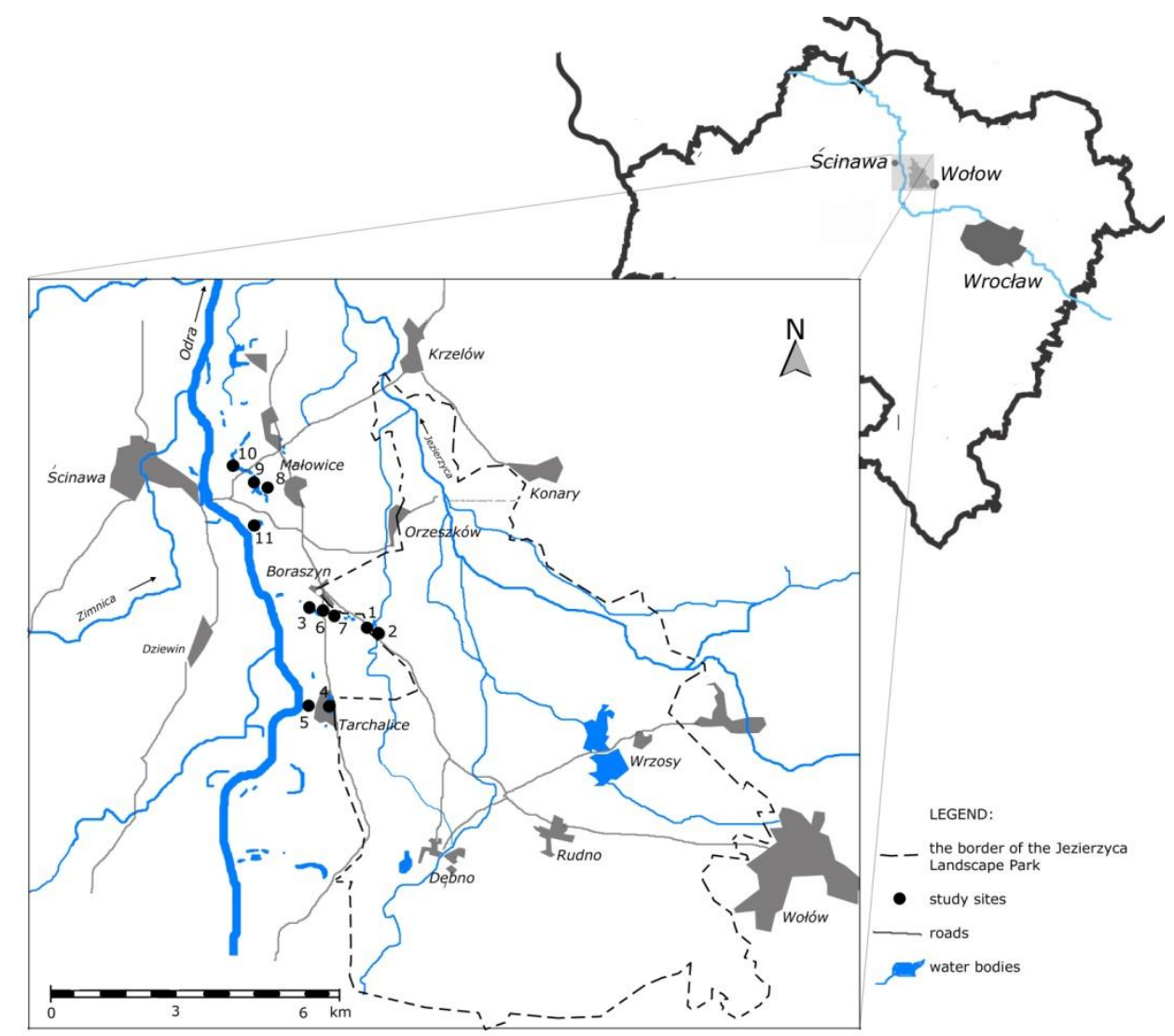

Fig. 1. Location of study sites 


\subsection{Sample collection}

The sampling was conducted in the middle summer of 2012, at the peak of the H. morsus ranae growing season. Leaves of H. morsus ranae were taken simultaneously with water and bottom sediment samples. Three samples were randomly collected from 3 plots of $1 \mathrm{~m}^{2}$ located in different parts of each reservoir.

The water samples were taken at depth of 0.5-1 $\mathrm{m}$ and they were kept in acidcleaned polyethylene bottles. The bottom sediment samples were collected using the stainless steel collector at an average soil depth of 0-30 cm. The plant material was washed thoroughly using water from the sampling sites and was then cleaned of any adhering material. After sampling the plant and sediment material was placed in plastic bags, which were sealed to avoid extraneous contamination.

\subsection{Sample analysis}

Prior to analysis, the water samples were filtered using a Whatman glass microfiber filter (GF/C) and acidified with concentrated nitric acid (65\%, pro analysis). The concentrations of $\mathrm{Zn}, \mathrm{Mn}, \mathrm{Fe}, \mathrm{Cu}$ were determined by atomic absorption spectrometry with electro thermal atomization (AVANTA PM by GBC Scientific Equipment). Mercury concentrations were determined using Advanced Mercury Analyser (AMA 254). The bottom sediment samples were air dried, passed through a $2 \mathrm{~mm}$ diameter sieve and pulverized with a mortar and a pestle. The plant material was washed thoroughly in distilled water, dried at $50^{\circ} \mathrm{C}$ to a constant weight and ground into a fine powder in a POLYMIX PXMFC 90 D laboratory mill. Homogenized plant and sediment material $(0.5 \mathrm{~g})$ was subsequently digested in an open system with concentrated nitric acid (65\%, pro analysis) and hydrogen peroxide (30\%, pro analysis). The concentrations of $\mathrm{Zn}, \mathrm{Mn}, \mathrm{Fe}$ and $\mathrm{Cu}$ were determined by atomic absorption spectrometry with flame atomization (AVANTA PM by GBC Scientific Equipment). Mercury concentrations were determined using Advanced Mercury Analyser (AMA 254). The bottom sediments and water $\mathrm{pH}$ were determined with the $\mathrm{pH}$ meter.

The precision of the measurements was determined by comparing the results of trace metal content in the solutions made from two separate weighted portions of each sample, which had been analysed using identical methods. All elements were measured against standards (Atomic Absorption Standard Solution from Sigma Chemical Co.). Results for sediments and plants were calculated on a dry weight basis. Blank samples were digested and analysed in the same manner. The reproducibility of the methods was compared to the results of an interlaboratory study through digesting and analysing reference materials INCT- 
OBTL-5 (Oriental Basma Tobacco Leaves, Institute of Nuclear Chemistry and Technology Warszawa Poland) and GBW 07402 Anthropogenic Soil (Institute of Geophysical and Geochemical Exploration Lanfang China). Values were found to be $98 \pm 4$ (percent \pm standard deviation).

\subsection{Statistical analysis}

Statistical differences between study sites in terms of concentrations of elements in bottom sediments, water and plants were evaluated by one-way ANOVA on log-transformed data to obtain a normal distribution of features [29]. Pearson regression and correlation coefficients $(n=33)$ were calculated to examine relationships between the concentrations of the elements in water and plant tissues [19]. The $t$ test was used to determine differences of element concentrations between the group of study sites located in agricultural areas (811) and the group of study sites with low farming activity (1-7) [22]. Statistical confidence was set at $\mathrm{p}=0.05$. To evaluate metal transfer from environment to plants, a bioaccumulation factor (BF) was calculated as a ratio of metal concentration in plant tissues to that dissolved in the surrounding water, as European frog-bit is free-floating plant. The value was calculated for each study site separately and then averaged $[1,25]$. All statistical calculations were carried out using the CSS-StatisticaStatsoft ${ }^{\mathfrak{O}}$ [21].

\section{RESULTS AND DISCUSSION}

The ranges of total metal contents in water, bottom sediment samples and leaves of H. morsus ranae examined in present study are summarized in Tab. 1 and 2. The mean concentrations of all elements, except of $\mathrm{Hg}$, in water, bottom sediments and plants differed significantly between study sites (ANOVA, $\mathrm{p}=0.05$ ).

The trace metal concentrations found in water and bottom sediments of examined ponds decreased in the order: $\mathrm{Fe}>\mathrm{Mn}>\mathrm{Zn}>\mathrm{Cu}>\mathrm{Hg}$. The concentrations of metals studied in the water and the bottom sediments were mostly within the ranges typical of European background values [8, 12, 28, 30] (Tab. 1) which shows that oxbow lakes studied can be regarded as relatively free from the influence of anthropogenic pollution. 
Table 1. Minimum/maximum values, mean \pm standard deviation (SD) of $\mathrm{pH}$ and concentrations of metals in water and bottom sediments in the study sites

\begin{tabular}{|c|c|c|c|c|c|}
\hline & Element & Min & $\operatorname{Max}$ & Mean \pm SD & $\begin{array}{l}\text { Geochemical } \\
\text { background }\end{array}$ \\
\hline \multirow{6}{*}{ 岕 } & $\mathrm{pH}$ & 7.09 & 9.46 & 7.99 & - \\
\hline & $\mathrm{Zn}\left[\mu \mathrm{g} \mathrm{dm}^{-3}\right]$ & 0.56 & 4.18 & $1.92 \pm 0.82$ & $0.5-1.5^{\mathrm{b}}$ \\
\hline & $\operatorname{Mn}\left[\mu \mathrm{g} \mathrm{dm}^{-3}\right]$ & BDL & 151 & $25.9 \pm 33.7$ & $20-60^{\mathrm{a}}$ \\
\hline & $\mathrm{Fe}\left[\mu \mathrm{g} \mathrm{dm}^{-3}\right]$ & BDL & 827 & $126 \pm 218$ & $10-1400^{\mathrm{a}}$ \\
\hline & $\mathrm{Cu}\left[\mu \mathrm{g} \mathrm{dm}^{-3}\right]$ & 0.45 & 2.22 & $1.37 \pm 0.43$ & $2^{\mathrm{b}}$ \\
\hline & $\mathrm{Hg}\left[\mu \mathrm{g} \mathrm{dm}^{-3}\right]$ & BDL & 0.4 & $0.1 \pm 0.1$ & $0.2-1.2^{\mathrm{a}}$ \\
\hline \multirow{6}{*}{ 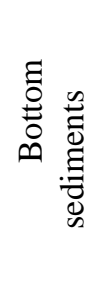 } & $\mathrm{pH}$ & 1.72 & 6.92 & 3.70 & - \\
\hline & $\mathrm{Zn}$ [mg kg ${ }^{-1}$ d.w.] & 2.67 & 320 & $25.4 \pm 57.1$ & $35^{\mathrm{d}}$ \\
\hline & $\mathrm{Mn}\left[\mathrm{mg} \mathrm{kg}^{-1}\right.$ d.w.] & 3.24 & 440 & $73.0 \pm 89.9$ & $500^{c}$ \\
\hline & $\mathrm{Fe}\left[\mathrm{mg} \mathrm{kg}^{-1}\right.$ d.w.] & 138 & 7625 & $1847 \pm 2285$ & $15000^{c}$ \\
\hline & $\mathrm{Cu}\left[\mathrm{mg} \mathrm{kg}^{-1}\right.$ d.w.] & $\mathrm{BDL}$ & 59.6 & $10.1 \pm 13.8$ & $9^{d}$ \\
\hline & $\mathrm{Hg}$ [mg kg${ }^{-1}$ d.w. $]$ & 0.003 & 0.338 & $0.064 \pm 0.146$ & $0.2^{\mathrm{a}}$ \\
\hline
\end{tabular}

${ }^{\mathrm{a}}[12],{ }^{\mathrm{b}}[8],{ }^{\mathrm{c}}[28],{ }^{\mathrm{d}}[30]$

BDL- below detection level, (limits of detection: $\mathrm{Cu} 0.001 \mathrm{mg} \mathrm{kg}^{-1}$; $\mathrm{Mn} 0.45 \mu \mathrm{g} \mathrm{dm}{ }^{-3}$; Fe $0.3 \mu \mathrm{g} \mathrm{dm}^{-3} ; \mathrm{Hg} 0.003 \mathrm{ng} \mathrm{kg}^{-1}$ )

Tab. 2. Minimum/maximum values, mean \pm standard deviation (SD) of concentrations of metals [ $\mathrm{mg} \mathrm{kg}^{-1}$ d.w.] in leaves of Hydrocharis morsus-ranae and bioaccumulation factors $(\mathrm{BF})$

\begin{tabular}{|c|c|c|c|c|c|}
\hline Element & Min & Max & Mean \pm SD & $\begin{array}{c}\text { Geochemical } \\
\text { Background }\end{array}$ & $\begin{array}{c}\mathrm{BF} \\
(\mathrm{mean} \pm \mathrm{SD})\end{array}$ \\
\hline $\mathrm{Zn}$ & 9.58 & 46.8 & $21.5 \pm 8.38$ & $10-17^{\mathrm{a}}$ & $12984 \pm 6706$ \\
\hline $\mathrm{Mn}$ & 120 & 6322 & $1979 \pm 1735$ & $20-500^{\mathrm{a}}$ & $\begin{array}{c}248597 \pm 33730 \\
9\end{array}$ \\
\hline $\mathrm{Fe}$ & 102 & 4798 & $997 \pm 1216$ & $50-200^{\mathrm{b}}$ & $55610 \pm 88352$ \\
\hline $\mathrm{Cu}$ & 0.01 & 20.6 & $4.09 \pm 3.39$ & $5-30^{\mathrm{a}}$ & $3499 \pm 3495$ \\
\hline $\mathrm{Hg}$ & 0.0056 & 0.0305 & $0.011 \pm 0.005$ & $0.02-0.5^{\mathrm{a}}$ & $141 \pm 164$ \\
\hline
\end{tabular}

The plant leaves differed from water and bottom sediments in respect of examined elements concentration sequence, which was as follows: $\mathrm{Mn}>\mathrm{Fe}>$ $\mathrm{Zn}>\mathrm{Cu}>\mathrm{Hg}$. The mean concentrations of $\mathrm{Zn}, \mathrm{Mn}$ and $\mathrm{Fe}$ were found to be relatively high and exceeded the physiological thresholds [12, 14]. The concentrations of $\mathrm{Mn}$ and $\mathrm{Fe}$ in leaves from some study sites were found to be within the toxic ranges for most plant species proposed by above-mentioned authors (400-1000 mg kg${ }^{-1}$ and $10-200 \mathrm{mg} \mathrm{kg}^{-1}$, respectively). Deviations from 
the natural contents in plant may indicate species that could be suitable for biomonitoring [17]. Compared to element concentrations in H. morsus ranae collected by other authors [2, 20, 30] in polluted regions, plants from area studied showed lower concentrations of $\mathrm{Cu}, \mathrm{Fe}$ and $\mathrm{Hg}$. However, concentrations of $\mathrm{Mn}$ and $\mathrm{Zn}$ were higher than noted in plants growing in contaminated water that were on average $816.78 \pm 36.43 \mathrm{mg} \mathrm{kg}^{-1}$ for $\mathrm{Mn}$ and ranged from 0.48 to $22.19 \mathrm{mg} \mathrm{kg}^{-1}$ for $\mathrm{Zn}[2,10]$.

The concentrations of $\mathrm{Fe}, \mathrm{Cu}$ and $\mathrm{Mn}$ in leaves of $H$. morsus ranae were higher than the ranges published for some other floating macrophyte species. Iron concentrations in plants from some study sites exceeded the concentrations found in shoots of Eichornia crassipes collected from metal-contaminated water bodies [1, 7], and also in Lemna sp. [24]. Concentrations of $\mathrm{Mn}$ in leaves from most study sites were higher than reported for water hyacinth [1, 9] (148 and $681 \mathrm{mg} \mathrm{kg}^{-1}$, respectively) but lower than in Lemna sp. and Salvinia sp. (2717 and $3000 \mathrm{mg} \mathrm{kg}^{-1}$, respectively) [5, 24]. Whereas $\mathrm{Cu}$ concentrations were lower than in Eichornia crassipes $[1,9,11]$ but higher than in Salvinia sp. collected from the area under intensive agricultural influence $\left(3.83 \mathrm{mg} \mathrm{kg}^{-1}\right)$ [5].

Study sites surrounded by fields (8-11) had significantly higher $\mathrm{Mn}$ concentrations in water than study sites with low farming activity ( $t$ test, $\mathrm{p}=0.05)$. Fertilizers and plant protection products are considered to be a significant source Mn [12]. Whereas the plants collected from study sites 1-7, located in non-agricultural regions, showed significantly greater accumulation of $\mathrm{Zn}$ and $\mathrm{Cu}$ ( $\mathrm{t}$ test, $\mathrm{p}=0.05$ ). This may be related to the fact that some of these study sites $(1,2,4,6$ and 7$)$ are situated near roads with high vehicle traffic [26]. These results are in agreement with statement that $\mathrm{Cu}$ and $\mathrm{Zn}$ comes principally from motor oil additives, tires, brake liners, metal corrosion, pavement and motorway material [7].

The mean values of bioaccumulation factor in leaves of $H$. morsus ranae are presented in Tab. 2. The decreasing trend of BF was the same as trend of metals concentrations in leaves of species studied. Obtained values are higher than reported for freshwater vascular plants in uncontaminated water, which were: 52857 for $\mathrm{Mn}, 2600$ for $\mathrm{Zn}$ and 1128 for $\mathrm{Cu}$ [6]. Compared to Eichhornia crassipes, a floating macrophyte that has been shown to hyper accumulate trace elements [6], $\mathrm{H}$. morsus ranae was characterized by higher factor of $\mathrm{Cu}, \mathrm{Mn}$ and $\mathrm{Zn}$ accumulation. In water hyacinth growing in the drain from industrial wastes and agricultural runoff in Australia, BF amounted up to 3879.6 for $\mathrm{Zn}$ and 595 for $\mathrm{Cu}$ [11]. Also bioaccumulation factors for Eichornia crassipes growing in metal-contaminated coastal water, which were: 68 for $\mathrm{Zn}, 43$ for $\mathrm{Cu}$ and 82 for $\mathrm{Mn}$ [1], were lower than for H.morsus ranae in our study. A high bioaccumulation factor for metals at low concentrations in surrounding 
environment is important for phytoremediation $[2,11]$. So species studied have a significant promise in the field.

Regarding trace metals correlation between plants and their environment, $H$. morsus ranae, as it is free-floating plant, is expected to show a relationship with the concentrations in water [6]. In our study, positive correlation expressed by Pearson's correlation $(\mathrm{p}<0.05)$ was found between $\mathrm{Zn}(0.39), \mathrm{Fe}(0.68)$ and $\mathrm{Hg}$ (0.57) concentrations in water and its accumulation in the leaves of species studied. Plants can be useful for ecological control when they show direct response to the environmental status [4].

\section{CONCLUSIONS}

Iron, $\mathrm{Zn}, \mathrm{Mn}, \mathrm{Cu}$ and $\mathrm{Hg}$ concentrations in water and bottom sediments at all studied locations were below the geochemical background, indicating no anthropogenic impact with respect to these metals.

Generally, the concentrations of $\mathrm{Zn}, \mathrm{Mn}, \mathrm{Fe}$ and $\mathrm{Cu}$ in leaves of H. morsus ranae exceeded the normal ranges stated in plants and reported for other freefloating macrophytes. Common frog-bit showed a high bioaccumulation factor for metals at low concentrations in surrounding environment. So species studied may be considered an accumulator of these metals. Plants growing near roads with high vehicle traffic show significantly greater accumulation of $\mathrm{Zn}$ and $\mathrm{Cu}$ than plants in agricultural regions.

The positive correlations between the content of metals in water and the level of these elements in the $H$. morsus ranae indicate that the plant is potentially useful for biomonitoring in general and for $\mathrm{Zn}, \mathrm{Fe}$ and $\mathrm{Hg}$ in particular.

\section{REFERENCES}

1. Agunbiade F.O., Olu-Owolabi B.I., Adebowale K.O.: Phytoremediation potential of Eichornia crassipes in metal-contaminated coastal water, Bioresource Technology, 100 (2009) 4521-4526.

2. Babovic N., Drazic G., Djordjevic A., Mihailovic N.: Heavy and Toxic Metal Accumulation in Six Macrophythe Species from Fish Pond Ecka, Republic of Serbita, BALWOIS - Ohrid, Republic of Macedonia 2010.

3. Baldantoni D., Maisto G., Bartoli G., Alfani A.: Analyses of three native aquatic plant species to assess spatial gradients of lake trace element contamination, Aquatic Botany, 83 (2005) 48-60.

4. Bonanno G.: Trace element accumulation and distribution in the organs of Phragmites australis (common reed) and biomonitoring applications, Ecotoxicology and Environmental Safety, 74 (2011) 1057-1064. 
5. Borišev M., Pajević S., Stanković Ž., Krstić B.: Macrophytes as phytoindicators and potential phytoremediators in aquatic ecosystems, Proceedings 36th International Conference of IAD, Austrian Committee Danube Research / IAD, Vienna, (2006) 76-80.

6. Brooks R.R., Robinson B.H.: Aquatic Phytoremediation by Accumulator Plants, in: Plants that Hyperaccumulate Heavy Metals: Their Roles in Phytoremediation, Microbiology, Archaeology, Mineral Exploration and Phytomining, ed. R.R. Brooks, Oxon, CAB International 1998, 203-226.

7. Campo G., Orsi M., Badino G., Giacomelli R., Spezzano P.: Evaluation of motorway pollution in a moutain ecosystem. Pilot project: Susa Valley (Northwest Italy) years 1990-1994, Science of the Total Environment, 189/190 (1996) 161-166.

8. Dojlido J.R.: Chemia wód powierzchniowych, Białystok, Wydawnictwo Ekonomia i Środowisko 1995.

9. El Falaky A.A., Aboulroos S.A., Saoud A.A., Ali M.A.: Aquatic plants for bioremediation of wastewater, 8th International Water Technology Conference IWTC8, Alexandria, Egypt, (2004) 361-376.

10. Gałczyńska M., Bednarz K.: Influence of water contamination on the accumulation of some metals in Hydrocharis morsus-ranae L. Journal of Elementology, 1 (2012) 31-41,

11. Hammad, D.M.: $\mathrm{Cu}, \mathrm{Ni}$ and $\mathrm{Zn}$ Phytoremediation and Translocation by Water Hyacinth Plant at Different Aquatic Environments, Australian Journal of Basic and Applied Sciences, 5, 11 (2011) 11-22.

12. Kabata-Pendias A., Pendias H.: Biogeochemia pierwiastków śladowych, Warszawa, Wydawnictwo Naukowe PWN 1999.

13. Maleva M.G., Nekrasova G.F., Bezel V.S.: The Response of Hydrophytes to Environmental Pollution with Heavy Metals, Russian Journal of Ecology, 35, 4 (2004) 230-235.

14. Markert B.: Presence and significance of naturally occurring chemical elements of the periodic system in the plant organism and consequences for future investigations on inorganic environmental chemistry in ecosystems, Vegetatio, 103 (1992) 1-30.

15. Martinez E.A., Shu-Nyamboli C.: Determination of selected heavy metal concentrations and distribution in a southwestern stream using macrophytes, Ecotoxicology and Environmental Safety, 74 (2011) 15041511.

16. O'Neill C.R.: European Frog-Bit (Hydrocharis morsus-ranae) - Floating Invader of Great Lakes Basin Waters, NYSG Invasive Species Factsheet Series, 07-1 (2007) 1-4., 
17. Otte M.L., Jacob D.L.: Chemical Fingerprinting of Plants from Contrasting Wetlands-Salt Marsh, Geothermal and Mining-impacted, Phyton, 45 (2005) 303-316.

18. Pajević S.P., Vučković M.S., Kevrešan Ÿ.S., Matavulj M.N., Radulovič S.B., Radnovič D.V.: Aquatic macrophytes as indicators of heavy metal pollution of water in DTD canal system. Proceedings for Natural Sciences, 104 (2003) 51-60.

19. Parker R.E.: Introductory Statistics for Biology, London, Edward Arnold Publishers Ltd. 1983.

20. Samecka-Cymerman A., Kempers A.J.: Rtęć $i$ inne metale ciężkie $w$ makrofitach z wybrancyh zbiorników Wroctawia i okolic, Acta Universitatis Wratenslaviensis, LIX (1994) 161-174.

21. StatSoft Inc., 2011. STATISTICA (data analysis software system), version 10. www.statsoft.com

22. Stanisz A.: Przystęny kurs statystyki, Kraków, StatSoft Polska Sp. z o.o. 1998.

23. Tutin T.G., Heywood V.H., Burges N.A., Moore D.M., Valentine D.H., Walters S.M., Webb D.A.: Flora Europaea, Cambridge, Cambridge University Press 1980.

24. Vardanyan L.G., Ingole B.S.: Studies on heavy metal accumulation in aquatic macrophytes from Sevan (Armenia) and Carambolim (India) lake System, Environment International, 32, 2 (2006) 208-218.

25. Wang W., Lewis M. A.: Metal accumualtion by aquatic macrophytes, in: Plants for Environmental Studies, red. W. Wang, J.W. Gorsuch, J.S. Hughes, CRC Press 1997, 367-416.

26. Weigle A. (ed.): Plan ochrony dla Parku Krajobrazowego „Dolina Jezierzycy" Operat generalny, Warszawa, Wrocław, Narodowa Fundacja Ochrony Środowiska 2011.

27. Węglarzy K.: Metale ciężkie - źródła zanieczyszczeń i wpływ na środowiska, Wiadomości Zootechniczne, R. XLV, 3 (2007) 31-38.

28. Woitke P., Wellmitz J., Helm D., Kube P., Lepom P., Litheraty P.: Analysis and assessment of heavy metal pollution insuspended solids and sediments of the river Danube, Chemisphere, 51 (2003) 633-642.

29. Zar J.: Biostatistical analysis, New Jersey, Prentice Hall 1999.

30. Zgłobicki W., Lata L., Plak A., Reszka M.: Geochemical and statistical approach to evaluate background concentrations of $\mathrm{Cd}, \mathrm{Cu}, \mathrm{Pb}$ and $\mathrm{Zn}$ (case study: Eastern Poland), Environmental Earth Sciences, 61 (2011) 347-355. 


\section{AKUMULACJA METALI CIĘŻKICH W LIŚCIACH HYDROCHARIS MORSUS- RANAE L. I MOŻLIWOŚCI JEGO ZASTOSOWANIA W BIOMONITORINGU}

\section{Streszczenie}

Rośliny wodne od lat znajdują zastosowanie w bioindykacji skażenia środowiska wodnego metalami śladowymi, ze względu na istniejącą zależność między zawartością pierwiastków w ich tkankach i w otaczającym je środowisku. Stopień kumulacji metalu zależy zarówno od rodzaju metalu, jak i od gatunku rośliny. Gatunek wskaźnikowy powinien być reprezentatywny dla obszaru badań, wszechobecny oraz latwy w identyfikacji i zbieraniu, a także charakteryzować się wysoką tolerancją na metale i wysokimi współczynnikami ich kumulacji.

Celem badań była ocena zdolności do akumulacji metali ciężkich przez Hydrocharis morsus-ranae oraz określenie jego przydatności w bioindykacji. Pobrano próbki wody, osadów dennych oraz liści żabiścieku pływającego z 11 zbiorników wodnych okolic Ścinawy. W próbkach oznaczono zawartości Hg, Mn, Zn, Fe i Cu. Zawartości metali w wodzie, osadach i roślinach wykazały istotne statystycznie różnice pomiędzy stanowiskami. Stężenia metali w wodzie i osadach dennych były niższe niż tło biogeochemiczne, co wskazuje na brak antropogenicznego zanieczyszczenia tymi metalami. Wysokie stężenia metali oraz wysokie współczynniki akumulacji w roślinach, a także dodatnie korelacje między zawartościami Zn, Fe i Hg w liściach H. morsus-ranae i wodzie wskazują na możliwość wykorzystania tego gatunku w biomonitoringu. Rośliny rosnące $\mathrm{w}$ zbiorniach wodnych zlokalizowanych przy drogach o silnym natężeniu ruchu charakteryzują się znacznie wyższą zawartością $\mathrm{Cu}$ i $\mathrm{Zn}$ od roślin rosnących w rejonach rolniczych.

Słowa kluczowe: metale cięzkie, Hydrocharis morsus ranae, akumulacja biomonitoring

Editor received the manuscript: $\quad 27.03 .2013$ 